\title{
RAD17 Gene
}

National Cancer Institute

\section{Source}

National Cancer Institute. RAD17 Gene. NCI Thesaurus. Code C91359.

This gene is involved in cell cycle regulation and DNA repair. 